\title{
BATMAN RIBONE (Batik Malangan Triple Bottomline) Implementation Triple Bottomline for Small Medium Enterprise (SME) in Malang Regency
}

\author{
Siti Amerieska*1, Galuh Kartiko', Novi Nugrahani ${ }^{1}$, Rika Wijayanti ${ }^{1}$, Farika Nikmah² \\ ${ }^{1}$ Department of Accounting, State Polytechnic of Malang, Jl. Soekarno Hatta 99, Malang, Indonesia, 65144 \\ ${ }^{2}$ Department of Business Administration, State Polytechnic of Malang, Jl. Soekarno Hatta 99, Malang, \\ Indonesia, 65144
}

Correspondence: Siti Amerieska (siti.amerieska@polinema.ac.id)

Received: 26 November 2020 - Revised: 6 January 2021 - Accepted: 8 January 2021

\begin{abstract}
Batik Malangan craftsmen SMEs need a presence in the world of business development. The main problems faced by batik SMEs are 1) lack of good management which covers Planning, Organizing, Actuating and Controlling (POAC) as the focus of management implementation within the context of developing Batik Malangan products, 2) lack of entrepreneurial funds, 3) lack of Batik Malangan socialization (marketing), owing to the lack of web and social media presence 4) Not having financial reports, especially reports within the framework of Triple Bottom Lines (Sustainability Report). The possible solutions are in the form of assistance in the preparation of management procedure systems and the establishment of a marketplace specializing in batik products of Malang. The methods used are in the form of mentoring and training on the use of the procedure system, and the application of a web-based marketplace. The results of this community service, with the existence of Batman Ribone standard operating procedure (SOP), which contains a production planning SOP, SME owners have become increasingly aware of the importance of production planning. The existence of this web-based marketplace increased the number of customers by up to $20 \%$ and has made it easier for them to access Batik Malangan products.
\end{abstract}

Keywords: Standard Operating Procedure, Batman Ribone

Citation Format: Amerieska S., Kartiko, G., Nugrahani, N., Wijayanti, R., \& Nikmah, F. (2021). BATMAN RIBONE (Batik Malangan Triple Bottomline) Implementation Triple Bottomline for Small Medium Enterprise (SME) in Malang Regency. Journal of Community Practice and Social Welfare, $1(1), 48-62$. 


\section{INTRODUCTION}

In 2014, the conception of Malangan Bambu Kenanga Batik Craftsmen Group begun in Turen Village. It was initiated by Widjayati, who had the determination and motivation to develop a promising business venture in her area by starting a Batik Malangan business. The business developed rapidly within the next five years. In her efforts, she mobilized the local community to participate in the development and improvement of family economy. They showed enthusiasm for her request. Based on a preliminary survey conducted by the community service team, on average they can process 20 to 50 pieces of batik. The amount of raw batik material that is processed daily varies greatly and cannot be predicted with certainty being that the process of making Batik Malangan is demand dependent. The workforce involved is on average 2 people for each craftsman (Rustiyaningsih, c 2019). The production process of each craftsman has something in common. The steps for Batik production in Turen Village, Malang Regency is as follows: 1) The fabric/batik is prepared for processing 2) Penyorekan, which is the process of tracing or making patterns, is applied 3) Pencantingan is a process carried out with wax using a tool called a cangting to trace patterns that had previously been sketched onto the fabric 4) Nembok, namely the process of covering with wax the parts that are to be kept undyed 5) dye-bathing/colouring, which is the process of dyeing fabric by dipping it into liquid dyes to get the desired colour 6) Pengerokan is the process of removing wax using a plate metal scraper 7) Nglorot is a process where the dyed cloth is boiled in hot water to remove the wax layer.

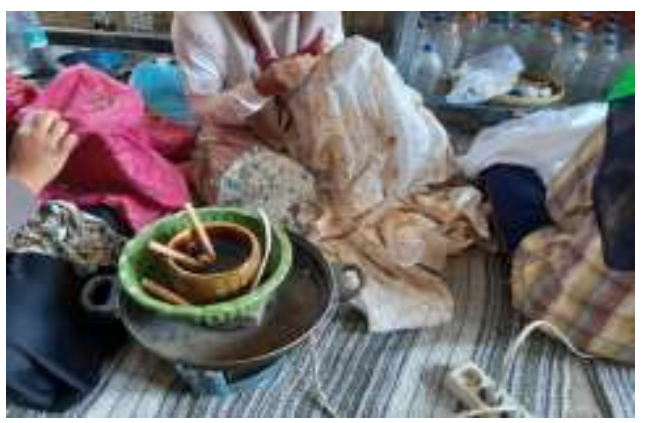

Figure 1. Production Process of Batik Malangan

\section{Management Aspects}

In general, the management systems of Bambu Kenanga Batik craftsmanship ventures are very simple and conventional, resulting in a difficulty to develop into larger businesses. The Bambu Kenanga craftsmen group conditions are detailed in table 1. 
Table 1. Management Data of Bambu Kenanga Batik Craftsmen

\begin{tabular}{ccc}
\hline No. & Conditional Aspects & Bambu Kenanga Batik Group \\
\hline 1 & Business age & 5 years \\
2 & Raw material Stock & Owned Stock is limited \\
3 & Crafting Method & Crafted based on order or demand \\
4 & Packaging & Nonexistent \\
5 & The existence of a user & Nonexistent \\
& manual & \\
6 & Promotional and marketing & Conventional and mouth to mouth \\
& methods & Not yet implemented \\
8 & Quality Control & Not enough funding \\
9 & Funding & Not done \\
\hline
\end{tabular}

Condition of management aspect: 1) The marketing system still relies on a conventional word-of-mouth method 2) There is no batik stocking system 3) Quality control has not been handled properly 4) There is no organized book-keeping.

Production Aspect: Up until today, the Malangan Bambu Kenanga Batik Craftsmen group still hasn't applied any acceptable management system on the scopes of Planning, Organizing, Actuating and Controlling (POAC). This issue is the focus for management implementation regarding the development of Batik Malangan products (Nindita et al., 2018). The following is the production data of the Malangan Bambu Kenanga Batik Craftsmen group.

\section{PROBLEMS}

The Malangan Bambu Kenanga Batik Craftsmen group has shown consistency and enthusiasm in developing Batik Malangan, but the group has some problems to solve. These problems, based on the observational survey results and interviews with the owners of the Kenanga Batik SME (Small, Medium Enterprise), are grouped into two main aspects, namely:

\section{Business management problem}

The limitation of knowledge about business management causes this community run conventional business management. One of the backgrounds might be the business of this community run from solidarity community or family business, the opposite of professional 
ones. According to Warnaningtyas (2020), the business should starts with professional and profitable management.

\section{Problems related to marketing technology/distribution}

The Bambu Kenanga Batik Malangan Craftsmen group has marketing problems that often plague small business owners/home industries. To them, production is not the main obstacle. It is how their products can penetrate the market. This is the main obstacle that is affecting most of the small industry players. Generally, the micro and small business products are in great demand by local and even foreign consumers, as evidenced by every exhibition that micro and small entrepreneurs had participated in where their merchandises are often sold-out. This relationship is often temporary (Warnaningtyas, 2020) as no further purchases are made to sustain their business. Several problems can be observed, namely:

a. Most micro and small entrepreneurs are product-oriented, not consumer-oriented. Most prefer to make products according to their tastes and are often satisfied with the products they produced without adjusting to consumers' preferences (Waluyo et al., 2019).

b. Many micro-business entrepreneurs view marketing as a luxury, resulting in many of these products not receiving any advertising treatment on the aspects of product design, packaging, and promotion.

c. There is a misunderstanding regarding micro-business marketing techniques where not every aspect of marketing is applied. For example, branding should not be a concern for micro-businesses which should focus more on product identifiers.

d. Marketing knowledge is still lacking, hence why micro and small-business entrepreneurs only apply traditional sales methods (Arifin, Muasyaroh, Prasetya, \& Samsiyati, 2020).

e. Many shops are not willing to accept product placement from micro-businesses as they are considered hard to sell and a waste of space.

\section{Funding aspects}

The most common problem faced by MSMEs (Micro, Small, Medium Enterprise) is limited funding. MSMEs may have many ideas for business development but were unable to execute them due to the lack of funds (Nindita et al., 2018). If traced back, many 
MSMEs have difficulty obtaining additional funding from financial institutions due to unmet requirements.

\section{IMPLEMENTATION METHOD}

This section describes the methods used to solve the problems. Based on observations, the appropriate implementation method of this community service is through the following: (as in Figure 2)

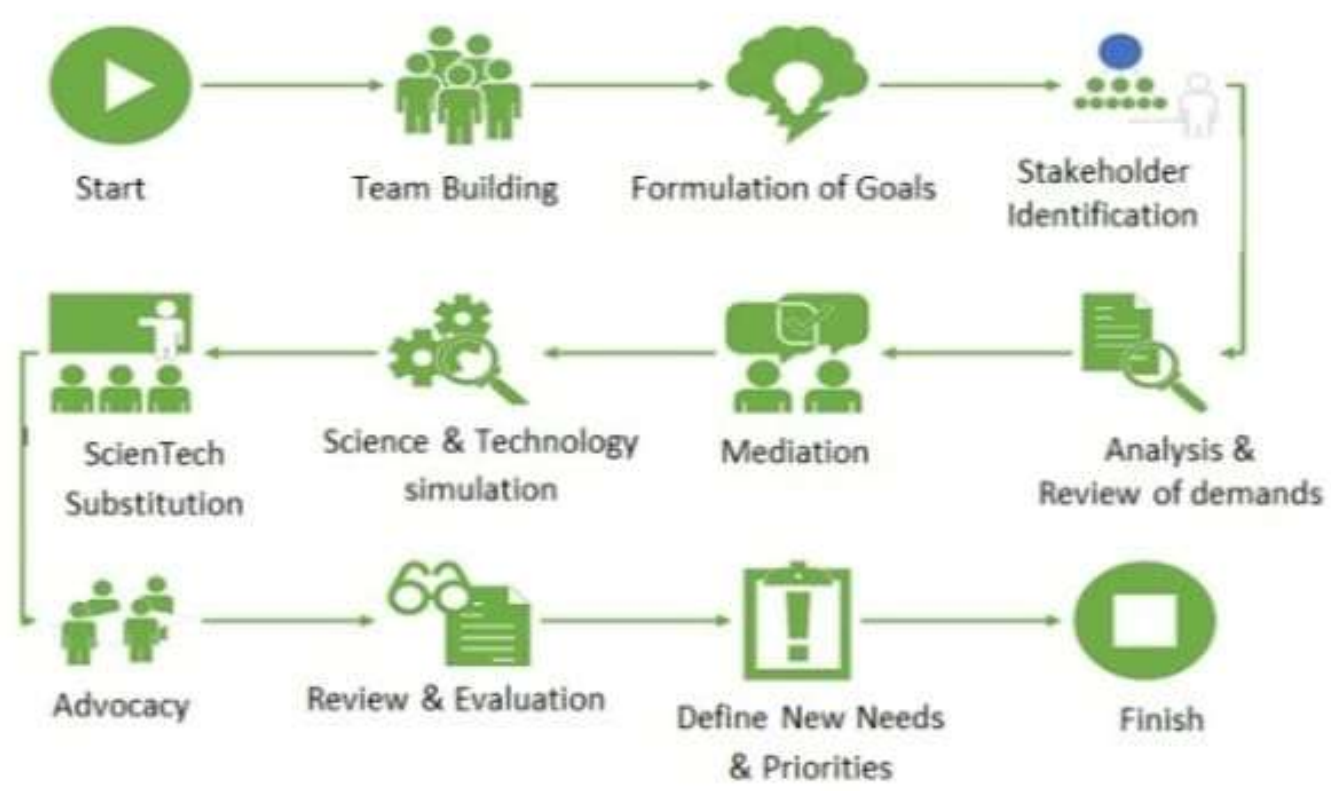

Figure 2. Implementation Method Diagram

a. Team building The formation of a team in community service activities aims to make it easier to coordinate according to the area of expertise of existing team members. The Batman Ribone community service team $(\mathrm{PkM})$ consists of five personnel who have expertise in law, marketing management, accounting, management accounting and taxation so that with the expertise of these team members can help implement $\mathrm{PkM}$ and can provide solutions to partner problems with knowledge and the experience of each personnel.

b. Formulation of goal. The formulation of PkM Batman Ribone's goals is carried out to understand the implementation map that will be carried out according to the target and the achievement of the solutions that will be given to partners. The formulation of PkM's goals is divided into two, namely business management, which will provide solutions to problems in management, production and economic aspects based on the Triple Bottomline (Profit, People and Planet). Meanwhile, the second formula 
concerns the aspects of marketing management which formulates the form of marketing batik products using technology.

c. Stakeholder identification. The identification of stakeholders here is a mapping of the parties related to the partners and the 'PkM Kemitraan' team. After being identified, it was found that there were several stakeholders who supported this activity, namely the Turen village government, which was believed to have a role in community empowerment in the village of Turen as well as supporting the PkM activities carried out by the team. Then the village-owned enterprises (BumDes) which has a role to provide business capital for MSMEs in a village.

d. Analysis \& review of demands. Analysis PkM partner socioeconomic data from preliminary surveys as the basis for formulating the implementation of PkM activities. As for the needs analysis, it is more based on what method is suitable to be carried out when it will provide a solution to the problem, matters related to infrastructure in the form of an LCD then some materials to be introduced to the batik industrial waste treatment. From our team, we listed a list of the needs needed starting from the permit for PkM activities during the Covid-19 period.

e. Mediation. Mediation is used for events in which the activity's trustee places itself as a mediator for the parties concerned and addresses community issues collectively.

f. Science \& technology simulation. Science technology simulation is used for the activity of informing the resulting product in the form of Batman Ribone standard operating procedures and a marketplace for selling batik products. This activity is intended to explain something that cannot be done in real time.

g. Science \& technology substitution. This activity offers new science and technology that is more modern and efficient than previous science and technology. Namely in the form of Batman Ribone standard operating procedures and a marketplace for selling batik products.

h. Advocacy. Assistance in the use of Batman Ribone SOP and website-based marketplaces. Advocacy aimed at partners to improve organizational management governance, entrepreneurial motivation and business planning and proposals. The training is intended so that partners have the expertise (skills) from the aspect of business activities whose solution has not been resolved in the consulting approach. In this approach, it is carried out after determining problems that require follow-up training from the results of consultations on all aspects of business activities, the method is 
called problem solving so that partners can have an increase in the production of independent and efficient masks that use environmentally friendly basic ingredients (natural dyes).

i. Review \& evaluation. The design of implementation and evaluation methods to be carried out (process evaluation, final and follow-up).

j. Define new needs \& priorities. After conducting the evaluation stage of the implementation of PkM activities, there are several things that need to be improved, both the service method carried out and the problems outside the original target. This is a challenge and an opportunity for the service implementation team to be able to find new targets as a basis for carrying out further service activities.

\section{RESULTS AND DISCUSSION}

\section{Implementation Process}

PkM Batman Ribone is a community service program in partnership between State Polytechnic of Malang (Polinema) and Batik Malangan SME. The team initiated the implementation of batik businesses management in Malang to spread awareness on the importance of the Triple Bottomline namely People, Planet, and Profit in running the Batik SMEs.

Batman Ribone is an acronym for Batik Malangan Triple Bottomline which is an Standard Operating Procedure (SOP) for the management of the Batik Malangan SMEs that emphasizes the importance of the People, Planet and Profit aspects within the operations of Batik SMEs.

The results achieved are divided into three aspects as mentioned in problems subsection. However, the discussion covers business management and marketing (distribution) aspects.

\section{Aspects of Business Management}

In this aspect of business management, the team created a business management operating procedure (SOP) in the form of business management procedures in the economic aspect, production related to environmental conservation and social aspects (Riduwan \& Andayani, 2018). The following is a form of the Batman Ribone SOP compiled by the team in order to understand of the business process in the Batman Ribone SOP: 
a. Profit aspect (economy): Batik Malangan SME produces batik in the form of handwritten batik, silk and printed batik. The various patterns of batik in Batik Malangan SME have developed a lot in their development. In addition to the motifs which are standard motifs, there are also many new motifs which are the intellectual work of Batik Malangan craftsmen. In order for this Batik Malangan SME to run on the right path, an SME Batik entrepreneur can run the SOP of Profit by understanding this Profit aspect calculating how much business capital is needed (Kurniawan, 2017) (Swainson \& Mahanty, 2018), where the capital is obtained, and how the financial planning including budgeting plan, cash flow, and so on.

b. Social Aspects (people): The second SOP Batman Ribone is community empowerment. This is a conceptual and development agenda that supports community capacity. The expected goal in this empowerment is to create an independent community life (Warnaningtyas, 2020), be it in the fields of education, economy, or also in the industrial sector. Batik SME is one of the media and facilitators of community empowerment (Sibarani, Sipayung, \& Supratman, 2020) (Swainson \& Mahanty, 2018).

c. Environmental Aspects (Planet): The introduction to the use of natural dyes began with training on making dyes from natural ingredients based on the SOP for making naturalcolored batik. Then the wastewater treatment plant (WWTP) was built as a pilot for the surrounding MSME (Peng, Zheng, Wei, \& Elahi, 2020). To treat batik-making wastewater, the wastewater is flowed to the wastewater installation through the inlet pit which then goes into the sediment pond. In this tub, the waste will coagulate and flocculate. This process is carried out by adding a certain amount of coagulant chemicals such as alum and polyaluminium chloride (PAC) to the waste accompanied by stirring so that it will produce floc (solids of large size) which will settle due to the influence of gravity (Warsito, 2018). The water is then flowed into the filtration tub which consists of three tubs, each containing zeolite, palm fiber, and fine sand (Pujotomo, Nugroho, \& Sihombing, 2019). After going through the filtration stage, the water is poured into the last tub for disinfection, to prevent microorganism contamination by adding disinfectants, such as chlorine and hypochlorite (Song, et al., 2019). Only after going through all these stages will water flow into the environment. With the construction of this WWTP, the aesthetics of the surrounding environment are preserved, and the unpleasant aroma is lost. 
Table 2 indicates the evaluation process consist of indicator criteria, success criteria, and instruments.

Table 2. The Batman Ribone Evaluation Mode

\begin{tabular}{|c|c|c|}
\hline $\begin{array}{c}\text { Aspect: Economy (Profit) } \\
\text { Indicator Criteria }\end{array}$ & Success Criteria & Instruments for Evaluations \\
\hline $\begin{array}{l}\text { a. SOP and book of } \\
\text { governance of } \\
\text { organizational management } \\
\text { books. } \\
\text { b. SOP of standards and } \\
\text { measures of entrepreneurial } \\
\text { motivation. } \\
\text { c. Have a business plan } \\
\text { proposal. } \\
\text { d. Have a capital access } \\
\text { database. }\end{array}$ & $\begin{array}{l}\text { a. There is an increase in } \\
\text { knowledge and capabilities of } \\
\text { business management } \\
\text { governance management of } \\
\text { the group of batik artisans in } \\
\text { Malang Bambu Kenanga. } \\
\text { b. There is an increase in } \\
\text { knowledge and abilities of } \\
\text { standards and measures of } \\
\text { entrepreneurial motivation. } \\
\text { c. There was an increase in } \\
\text { knowledge and ability to make } \\
\text { business planning proposals. } \\
\text { d. There was an addition to the } \\
\text { capital access database. }\end{array}$ & $\begin{array}{l}\text { a. Able to make and use SOPs } \\
\text { and Management Books for } \\
\text { management books of the } \\
\text { Batik Malangan craftsmen } \\
\text { group, Bambu Kenanga } \\
\text { b. Able to create and use SOP } \\
\text { and entrepreneurial } \\
\text { motivation measures. } \\
\text { c. Able to make and use a } \\
\text { business plan proposal to } \\
\text { raise funds/capital. } \\
\text { d. Able to create and use } \\
\text { capital access database. }\end{array}$ \\
\hline
\end{tabular}

\section{Aspect: People (Social)} Indicator Criteria

a. Database link or partner network.

b. Network (network) with government agencies /private.

c. Reliable and able to operate a web site/social media.
Success Criteria

a. There is an increase in the ability and skills to create database links or partner networks.

b. There was an increase in the ability and skills to network with government/private agencies.

c. There was an increase in the ability and skills to operate a web site/social media.
Instruments for Evaluations

a. Availability of database link or partner network.

b. There was an increase in the ability and skills to network with government/private agencies.

c. There was an increase in the ability and skills to operate a web site/social media.

\section{Aspect: Planet (environment)}

Indicator Criteria

a. Independent and efficient Batik Malangan (material of newsprint/cardboard and the like) which is environment friendly.

b. Reliable and able to organize workers/members of the Malang Bambu Kenanga batik craftsman group and the surrounding community as a batik center for Batik Malangan as part of the Corporate Social Responsibility (CSR).
Success Criteria

a. There has been an increase in the ability and skills to make independent Batik Malangan and efficient which is environment friendly.

b. There was an increase in the ability and skills of organizing the workforce/members of the batik craftsmen group and the surrounding community as the center for Batik Malangan.
Instruments for Evaluations

a. Able to make Batik Malangan competitive and efficient as a source of income/prosperity for themselves, families and groups of batik artisans in Malang Bambu Kenanga.

b. Able to organize the workforce/members of the Malangan Batik craftsmen group and the surrounding community as part of the Corporate Social Responsibility (CSR). 
In addition to the $\mathrm{PkM}$ team preparing SOP, they also prepared a continuous report of Triple Bottomline opportunities and benefits of SMEs in conducting sustainability. It is interesting to observe the opinion which states that CSR in large companies must be based on stakeholder theory, while CSR carried out on SMEs must be based on the concept of social capital (Nindita, et al., 2018). This is very interesting to observe because the interests of companies in large industries and SMEs are very different. Large companies carry out CSR activities because they require strong legitimacy from all stakeholders so that the sustainability of the company's business can continue. Some literatures also explain that sometimes the motivation of large companies in carrying out CSR is just an image. In (Waluyo, et al., 2019), the implementation of CSR can be effective and is more than just an activity for imaging company management and concludes that in some ways SMEs can take.

The method of implementation for this PkM activity uses a participatory method approach which provides instructions on the use of Batman Ribone SOP. The activity is in the form of mentoring and is intended for the improvement of participants' governance of organizational management, entrepreneurial motivation, and business planning proposals (business plan). Figure 3 illustrates the socialization of SOP event.

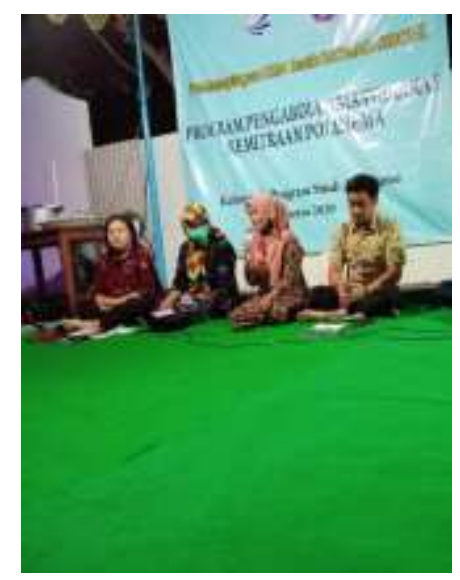

Figure 3. Socialization of Batman Ribone SOP

Training approach was carried out after determining the problems that require follow-up trainings obtained from the results of consultations on all aspects of business activities. This method was called Problem Solving for the purpose of increasing partner's independent and efficient production of masks using environmentally friendly raw materials (natural dyes) (Warsito, 2018). 
Partner assistance was intended for the application of the results of consultation and training, where the team conducts evaluation and assistance in applying all aspects of business activities to help partners determine and decide the best strategies for handling obstacles. This is done to help partners build partnerships or collaborations with both government and private agencies and gain investment/donor/sponsorship and the development of social communication and promotion. Benefits of the activity: The benefits of this activity were communicated by one of the leaders of the batik group, Mr.

Ali Widodo, he said:

"that initially, the business management carried out so far has already been referencing the Triple Bottomline. Despite this, the implementations were not carried out continuously, such as in the use of natural dyes where the batik waste management process would sort out hazardous wastes or not".

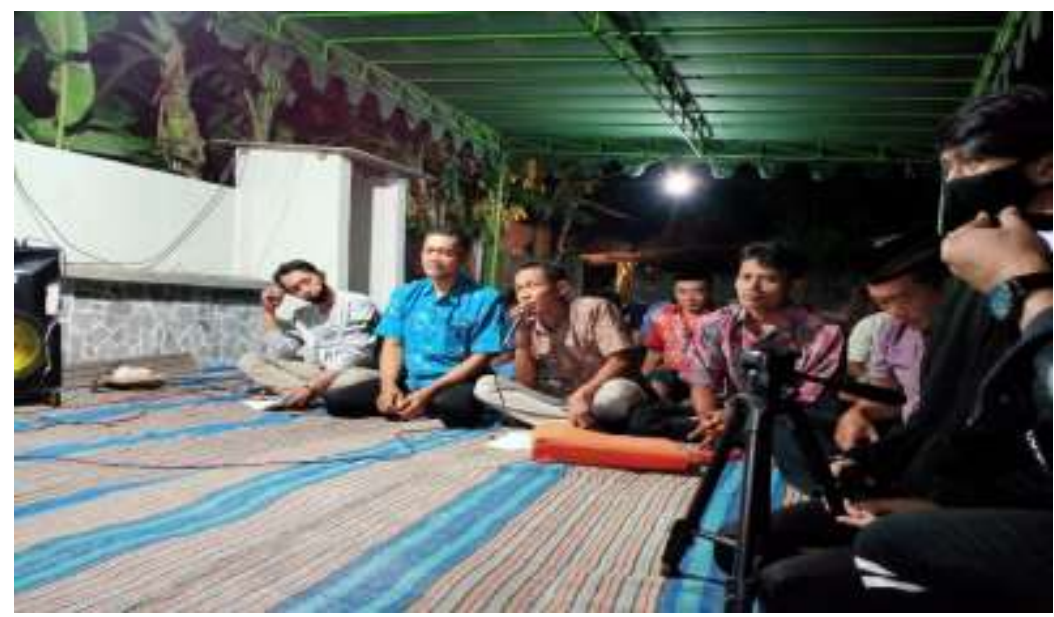

Figure 4. Sharing evaluation results of PKM Implementation

With the existence of the Polinema PkM Team, Mr. Ali felt greatly aided by the Batman Ribone SOP instructions, namely on how to manage waste naturally and economically. On the other hand, Mrs. Ima, as a fellow owner of a Batik Malangan SME, also presented Batman Ribone SOP to locals on how the social process empowers the community by encouraging them to join her batik business venture.

\section{Marketing and Distribution Aspects}

In order to provide solutions for the marketing and distribution aspects of the PkM partnership team, Polinema created a website-based marketplace with the name Jomliki Mart, the website address contains contact information includes cell phone numbers, 
Whatsapp, Instagram, Facebook, and Telegram (Arifin, et al., 2020). The website illustration as in Figure 5. The payment feature provides prospective buyers with a variety of payment methods. Payment can be made in person, or via mobile banking or other online payment applications (Kristanti, 2013). The shipping charge feature is a delivery feature which provides logistics delivery services.

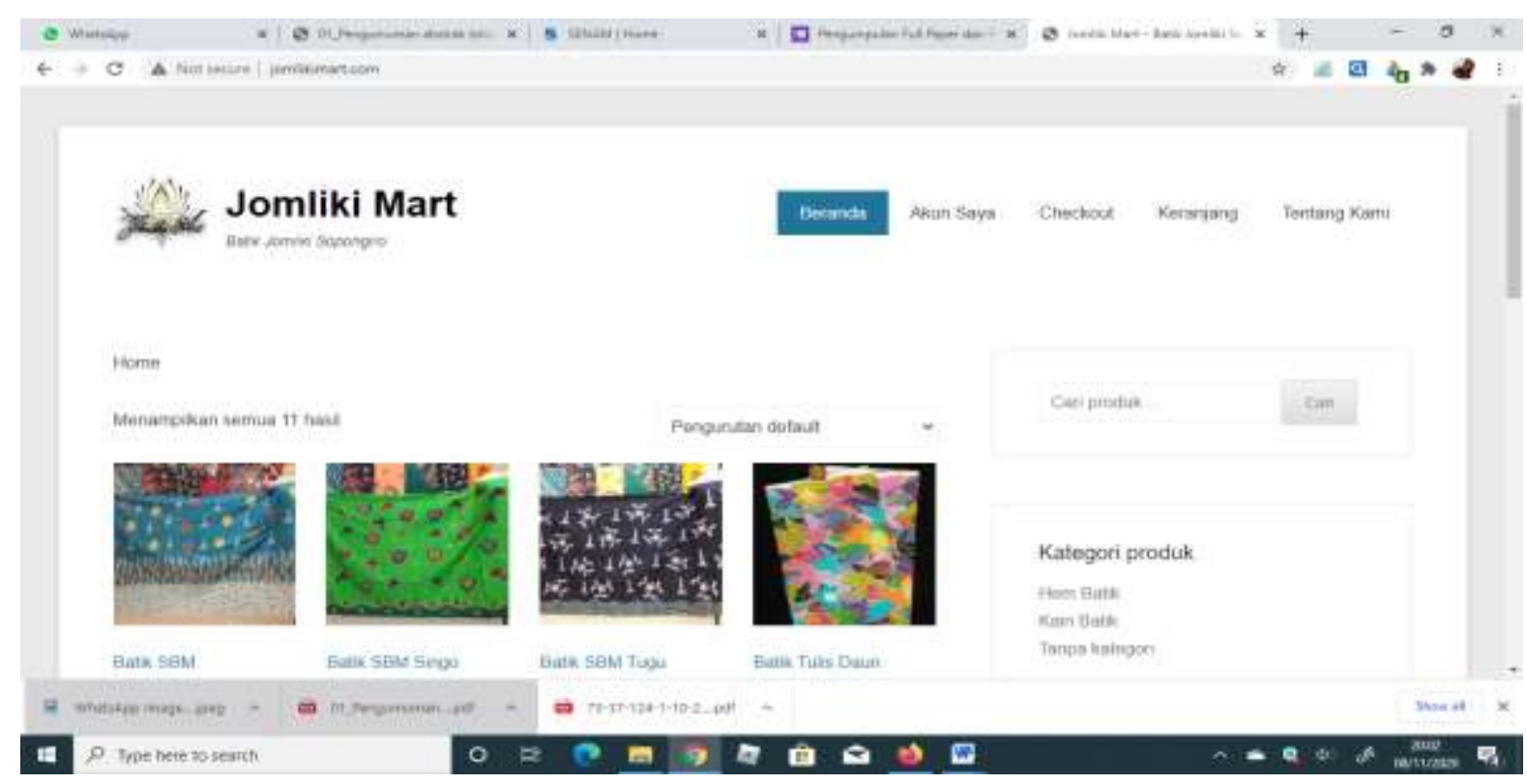

Figure 5. SME web marketing through Jomlikimart.com (online per January 8, 2021)

Table 3. The Conclusion Remark

\begin{tabular}{|c|c|c|c|c|}
\hline No. & Scope of Problem & Offered Solutions & Output Target & $\begin{array}{c}\text { Outcome } \\
\text { Indicators }\end{array}$ \\
\hline 1. & $\begin{array}{c}\text { Business } \\
\text { Management } \\
\text { Aspects }\end{array}$ & $\begin{array}{l}\text { The use of recording } \\
\text { systems ranges from } \\
\text { Triple Bottomline based } \\
\text { production planning, } \\
\text { production, and } \\
\text { marketing. }\end{array}$ & $\begin{array}{c}\text { Implementation } \\
\text { of one unit } \\
\text { Operating Sistem } \\
\text { Procedure (SOP) } \\
\text { (Batman Ribone) }\end{array}$ & $\begin{array}{l}\text { Improvements of } \\
\text { production planning } \\
\text { and production } \\
\text { quality. }\end{array}$ \\
\hline 2. & $\begin{array}{c}\text { Marketing } \\
\text { Technology } \\
\text { Aspect/Distribution }\end{array}$ & $\begin{array}{l}\text { Marketing of Batik } \\
\text { Malangan SME using } \\
\text { technology in the form of } \\
\text { websites and social } \\
\text { media, }\end{array}$ & $\begin{array}{l}\text { Websites in the } \\
\text { form of } \\
\text { marketplace, and } \\
\text { ownership of } \\
\text { social media } \\
\text { account, } \\
\text { Instagram. }\end{array}$ & $\begin{array}{l}20 \% \text { increase of } \\
\text { customer numbers }\end{array}$ \\
\hline 3. & Funding Aspects & $\begin{array}{l}\text { The addition of electric } \\
\text { stoves to increase } \\
\text { production capacity. }\end{array}$ & Four units & $\begin{array}{l}20 \% \text { increase of } \\
\text { customer numbers }\end{array}$ \\
\hline
\end{tabular}


One of the solutions offered in this activity is the creation of an online-based Malangan Batik marketplace application. The online application, named Jomliki Mart, has several features that simplify the process of online buying and selling. These features includes information on Malangan Batik products. Seller contact information feature for prospective buyers. Table 3 conclude the results of this community services.

\section{CONCLUSION}

The implementation of Batman Ribone PkM provides a view for what is to come for the PkM Team in providing business management assistance using technology. The SOP manual will be implemented through the Internet of Things. It is hoped that SMEs can easily take advantage of the SOP. As a follow-up, the PKM program will also continue to assist budding entrepreneurs in solving problems effectively. Additionally, batik craftsmen partners which are household names such as Batik Bambu Kenanga and Batik Blimbing will still be involved in experience sharing and exhibitions with other partners. The team would also conduct periodic evaluations of partners' Success in running new or developing businesses.

\section{ACKNOWLEDGEMENT}

The team would like to thank the State Polytechnic of Malang for funding the PKM Program, the Batik Bambu Kenanga Turen for a willingness to become a partner in this PKM program, as well as the PKM members and Malang State Polytechnic accounting students.

\section{REFERENCES}

Waluyo, L.A.S., Srimulyani, V.A., \& Rustiyaningsih, S. (2019). PKM Kerajinan Batik Ecoprint dan Tie Dye di Kota Madiun dan Ponorogo. ASAWIKA: Media Sosialisasi Abdimas Widya Karya, 4(02), 6-10. https://doi.org/10.37832/asawika.v4i02.4

Arifin, Z., Muasyaroh, H., Prasetya, A.B., \& Samsiyati, N. (2020). Inovasi Penjualan Batik Berbasis Online di Desa Paseseh Kecamatan Tanjungbumi Kabupaten Bangkalan. $J$ ABDIPAMAS (Jurnal Pengabdian Kepada Masyarakat). IKIP-PGRI Bojonegoro, 4(2), 81-89.

Kristanti, M. M. (2013). Green Marketing melalui Higher Net Sustainable Value sebagai 
Sumber Keberlanjutan Kemajuan Proses Bisnis dan Kemakmuran untuk Perusahaan Skala Kecil Menengah Indonesia. Proceeding Seminar Nasional dan Call For Papers Sancall, 76-81.

Kurniawan, P.S. (2017). Pemodelan Proses Penyusunan Laporan Keberlanjutan pada Usaha Kecil dan Menengah (UKM). Jurnal Akuntansi dan Keuangan Akuntabel, 14(1), 29-37. https://doi.org/10.29264/jakt.v14i1.1153

Nindita, V., Hidayati, N., Sumiyarso, B., \& Anggrahini,V.S. (2018). Kerajinan Batik Wonogiren dalam Upaya Menuju Ekspor Melalui "Green Product" dan Ekoefisiensi. Jurnal Dianmas, 7(2), 99-104.

Peng, B., Zheng, C., Wei, G., \& Elahi, E. (2020). The cultivation mechanism of green technology innovation in manufacturing industry: From the perspective of ecological niche. Journal of Cleaner Production, 252 (119711). https://doi.org/10.1016/j.jclepro.2019.119711

Pujotomo, D., Nugroho, S., \& Sihombing, I. G. (2019). Analisis Tingkat Eko-Efisiensi Pada Pewarna Batik dengan Menggunakan Metode Life Cycle Assessment (Lca) Pada UKM Batik Semarang 16. Seminar Nasional IENACO, 172-178.

Riduwan, A., \& Andayani, A. (2018). Peran Akuntansi dalam Pertanggungjawaban SosioEkologi. Jurnal Akuntansi Multiparadigma, 9(2), 205-222. https://doi.org/10.18202/jamal.2018.04.9012

Sibarani, M., Sipayung, E., \& Supratman, D. (2020). Business Model Based on Green Business, Which Can Increase the World Market in Ceramic SMEs in Integrated District, Purwakarta District. Jurnal Sosial Humaniora, 11(1), 65-74 https://doi.org/10.30997/jsh.v11i1.2437

Song, M., Fisher, R., \& Kwoh, Y. (2019). Technological challenges of green innovation and sustainable resource management with large scale data. Technological Forecasting and Social Change, 144, 361-368. https://doi.org/10.1016/j.techfore.2018.07.055

Swainson, L., \& Mahanty, S. (2018). Green economy meets political economy: Lessons from the "Aceh Green" initiative, Indonesia. Global Environmental Change, 53, 286295. https://doi.org/10.1016/j.gloenvcha.2018.10.009

Warnaningtyas, H. (2020). Desain Bisnis Model Canvas (BMC) pada Usaha Batik Kota Madiun. 9(79), 52-65.

Warsito, B. (2018). Pengelolaan Limbah Batik Cair Secara Biologis Pada Ukm Batik Mutiara Hasta Dan Katun Ungu Semarang. Warta LPM, 21(2), 136-142. https://doi.org/10.23917/warta.v21i2.5602

(C) 2021 by authors. Content on this article is licensed under a Creative Commons Attribution 4.0 International license. (http://creativecommons.org/licenses/by/4.0/). 
Original Title:

BATMAN RIBONE (Batik Malangan Triple Bottomline) pada Pengrajin Batik Bambu Kenangan Kabupaten Malang

Abstrak. UKM Pengrajin Batik Malangan, perlu eksistensi dalam pengembangan usaha. Adapun masalah utama yang dihadapi UKM batik adalah 1) belum memiliki tatakelola manajemen yang baik meliputi Planning, Organizing, Actuating, Controlling (POAC) menjadi fokus implementasi manajemen dalam rangka pengembangan produk batik Malangan, 2) minimnya dana kewirausahaan, 3) minimnya sosialisasi (pemasaran) batik Malangan karena belum memiliki web dan medsos, 4) belum mempunyai laporan keuangan khususnya laporan keuangan yang berbasis Triple Bottom Lines (laporan keberlanjutan). Solusi yang ditawarkan berupa pendampingan penyusunan sistem prosedur manajemen tata kelola dan pembuatan marketplace khusus produk Batik Malangan. Metode yang digunakan berupa pendampingan dan pelatihan penggunaan sistem prosedur dan pengaplikasian penggunaan marketplace berbasis website. Hasil pengabdian ini dengan adanya standard operating procedure (SOP) Batman Ribone yang didalamnya terdapat SOP perencanaan produksi maka para pelaku UMKM semakin menyadari pentingnya perencanaan produksi dan adanya marketplace berbasis website ini berdampak terdapat peningkatan $20 \%$ jumlah pelanggan, yang mana mereka lebih mudah mengakses produk-produk Batik Malangan.

Kata kunci: Standard Operating Procedure, Batman Ribone 